\title{
Ekonomi Politik Kebijakan Pemerintah Kabupaten Cirebon dalam Peningkatan Sektor-Sektor Ekonomi Unggulan di Kabupaten Cirebon
}

\section{The Political Economy of Government Policy in Improving Leading Economic Sectors in Cirebon Regency}

\author{
Ayu Sri Utami Hendriani dan Muhammad Findi A \\ Alumni Program Studi Ekonomi Studi Pembangunan (ESP) FEM IPB \\ Dosen FEM IPB dan Kadiv Kebijakan Publik Syariah CI-BEST IPB
}

\begin{abstract}
Economic growth is one of the main indicators reflecting the success of economic development. Basically, economic development is a series of efforts to raise incomes, to expand employment, to improve economic relations among the regions and to seek a shift of economic activity from the primary sector to the secondary sector even tertiary sector. Various economic sectors are interrelated with each other in order to promote economic growth in the region. It needs a great support from the central and local government, and also the stakeholders through regulation, so as to create prosperity for its people. This study analyzes the economic sectors in Cirebon Region which includes the leading sectors in the period 2005-2010. The data used are the West Java GDP and GDP of Cirebon in the 2005-2010 at constant prices of 2000 analyzed by Shift Share method (SS). Based on the analysis of the Shift Share method, leading sectors experiencing rapid growth are building/construction, trade, hotels and restaurants, transport and communications, finance, leasing and services companies. While the sector that has a good competitiveness is the services sector. Based on the results, the effective policy launched by the Cirebon Leader and its Government is considered as one of the main elements of Cirebon economic and local political stability.
\end{abstract}

\section{Keywords: Cirebon, Policy, Leading Economic Sector}

\begin{abstract}
Abstrak. Pertumbuhan ekonomi adalah salahsatu indikator keberhasilan pembangunan. Pada dasarnya pembangunan ekonomi adalah serangkaian usaha untuk meningkatkan pendapatan masyarakat, memperluas lapangan pekerjaan, meningkatkan hubungan ekonomi antardaerah dan mengupayakan terjadinya pergeseran kegiatan ekonomi yang semula dari sektor primer kepada sektor sekunder bahkan sektor tersier. Berbagai sektor-sektor ekonomi saling berkaitan antara satu sama lain, guna memajukan pertumbuhan ekonomi pada suatu wilayah. Perlu adanya dukungan yang besar dari pemerintah pusat dan Pemerintah kabupaten Cirebon dan pihak terkait melalui regulasi yang dibuatnya, sehingga tercipta kesejahteraan bagi masyarakatnya. Penelitian ini menganalisis sektorsektor ekonomi di Kabupaten Cirebon yang termasuk sektor unggulan dalam periode tahun 2005-2010. Data yang digunakan yaitu PDRB Provinsi Jawa Barat dan PDRB Kabupaten Cirebon dalam periode tahun 2005-2010 atas dasar harga konstan tahun 2000. metode analisis Shift Share (SS). Berdasarkan analisis Shift Share, sektor unggulan yang mengalami pertumbuhan yang cepat yaitu terdapat pada sektor bangunan/konstruksi, sektor perdagangan, hotel dan restoran, sektor pengangkutan dan komunikasi, sektor keuangan, persewaan dan jasa perusahaan. Sedangkan sektor yang memiliki dayasaing yang baik yaitu sektor jasa-jasa. Berdasarkan hasil penelitian yang didapat, maka kebijakan yang efektif oleh Bupati dan jajaran Pemerintah Kabupaten Cirebon sebagai salahsatu unsur penggerak ekonomi dan politik lokal, mutlak ditetapkan dalam upaya meningkatkan sektor ekonomi unggulan yang memiliki dayasaing yang baik untuk pertumbuhan ekonomi dan kestabilan politik masyarakat kabupaten Cirebon yang lebih baik.
\end{abstract}

Kata kunci: Kabupaten Cirebon, Kebijakan, Sektor Ekonomi Unggulan 


\section{PENDAHULUAN}

Indonesia memiliki kondisi geografi wilayah yang beragam sehingga struktur ekonomi tiap wilayah sangat beragam. Dalam hal ini pembangunan wilayah menjadi sangat penting perannya terhadap pembangunan nasional. Sebagaimana tertuang dalam GBHN (Garis-Garis Besar Haluan Negara) bahwa pembangunan ekonomi merupakan salah satu bagian terpenting dari pembangunan nasional yang bertujuan sebagaimana dalam al-Qur'an yaitu untuk mencapai negeri yang sejahtera dan dengan lindungan dari Allah SWT yang Maha Pengampun (Q.S. Saba' (34): 15).

Pertumbuhan ekonomi adalah salah satu indikator keberhasilan pembangunan. Semakin tinggi pertumbuhan ekonomi, maka semakin tinggi pula kesejahteraan masyarakatnya diluar indikator yang lain. Manfaat dari pertumbuhan ekonomi itu sendiri adalah untuk mengukur kemajuan ekonomi sebagai hasil pembangunan nasional maupun pembangunan daerahnya (Putong, 2003).

Pembangunan daerah selalu memprioritaskan usaha-usaha yang mendukung guna membangun serta memperkuat sektor-sektor ekonomi di setiap wilayahnya. Menurut Badan Pusat Statistik, sektor ekonomi tersebut terbagi menjadi sembilan sektor yaitu :
1) pertanian;
2) pertambangan dan penggalian;
3) industri pengolahan;
4) listrik,gas,dan air bersih;
5) konstruksi/bangunan;
6) perdagangan, hotel dan restoran;
7) pengangkutan dan komunikasi;
8) keuangan, persewaan dan jasa perusahaan;
9) jasa-jasa.

Sembilan sektor ekonomi tersebut terbagi menjadi sektor primer, sektor sekunder dan sektor tersier. Sektor primer meliputi: pertanian dan pertambangan, kemudian sektor sekunder meliputi: industri pengolahan, listrik, gas dan air bersih, dan konstruksi/bangunan. Sedangkan sektor tersier meliputi: perdagangan, pengangkutan, keuangan, persewaan dan jasa-jasa.

Pada dasarnya pembangunan ekonomi adalah serangkaian usaha untuk meningkatkan pendapatan masyarakat, memperluas lapangan pekerjaan, pemerataan pembagian pendapatan, meningkatkan hubungan ekonomi antardaerah, mengupayakan terjadinya pergeseran kegiatan ekonomi yang semula dari sektor primer kepada sektor sekunder serta sektor tersier.

Sejak diberlakukannya otonomi daerah pada tahun 2001, seharusnya pemerintah daerah harus lebih leluasa untuk meningkatkan pembangunan wilayahnya agar tercapai pembangunan nasional yang nantinya akan memperkokoh dan meningkatkan pertumbuhan ekonomi baik daerah maupun nasional. Hal itulah yang terlihat dan seharusnya ditingkatkan di daerah Kabupaten Cirebon.

Kabupaten Cirebon adalah daerah dimana terdapat banyak sumberdaya yang seharusnya dapat dioptimalkan sehingga dapat meningkatkan pertumbuhan ekonomi di daerah tersebut. Kabupaten Cirebon juga terkenal akan sentra industri pengolahan rotannya dan usaha udangnya.

Pada Tabel 1.1. PDRB Kabupaten Cirebon selalu meningkat dari tahun ke tahunnya, yaitu pada tahun 2005 atas harga konstan tahun 2000 adalah sebesar 6.343 .779 juta rupiah, sedangkan pada tahun 2010 mengalami peningkatan menjadi sebesar 8.130.325,07 juta rupiah 
Tabel 1.1. Produk Domestik Regional Bruto (PDRB) Kabupaten Cirebon Atas Dasar Harga Konstan 2000 Menurut lapangan Usahanya 2005-2010 (Juta Rupiah)

\begin{tabular}{|c|c|c|c|c|c|c|}
\hline \multirow{2}{*}{ Lapangan Usaha } & \multicolumn{6}{|c|}{ PDRB Atas Dasar Harga Konstan 2000} \\
\hline & 2005 & 2006 & 2007 & 2008 & $2009 *)$ & $2010 * *)$ \\
\hline 1. Pertanian & 1.989 .626 & 1.991 .037 & 2.106 .894 & 2.220 .658 & 2.363 .237 & $2.442 .050,77$ \\
\hline $\begin{array}{l}\text { 2. Pertambangan/ } \\
\text { Penggalian }\end{array}$ & 26.237 & 27.683 & 26.458 & 29.037 & 30.170 & $32.019,35$ \\
\hline $\begin{array}{l}\text { Industri } \\
\text { Pengolahan }\end{array}$ & 1.003 .855 & 1.062 .537 & 1.073 .203 & 1.105 .024 & 1.097 .080 & $1.097 .542,23$ \\
\hline $\begin{array}{l}\text { 4. Listrik, Gas } \\
\text { dan Air Bersih }\end{array}$ & 131.926 & 139.506 & 149.427 & 156.431 & 166.376 & $175.847,56$ \\
\hline $\begin{array}{l}\text { 5. Bangunan/ } \\
\text { Kontruksi }\end{array}$ & 421.073 & 456.040 & 499.538 & 531.654 & 562.036 & $605.021,72$ \\
\hline $\begin{array}{l}\text { 6. Perdagangan, } \\
\text { Hotel dan } \\
\text { Restoran }\end{array}$ & 1.400 .054 & 1.527 .252 & 1.589 .629 & 1.677 .752 & 1.784 .925 & $1.873 .433,74$ \\
\hline $\begin{array}{l}\text { 7. Pengangkutan } \\
\text { dan } \\
\text { Komunikasi }\end{array}$ & 369.852 & 398.213 & 425.734 & 430.154 & 448.764 & $482.727,89$ \\
\hline $\begin{array}{l}\text { 8. Keuangan, } \\
\text { Persewaan dan } \\
\text { Jasa } \\
\text { Perusahaan } \\
\end{array}$ & 274.813 & 291.765 & 303.119 & 318.562 & 333.638 & $356.997,47$ \\
\hline 9. Jasa-Jasa & 726.344 & 773.707 & 850.561 & 902.351 & 955.121 & $1.064 .684,34$ \\
\hline Total PDRB & 6.343 .779 & 6.670 .000 & 7.026 .564 & 7.371.622 & 7.746 .385 & 8.130.325,07 \\
\hline
\end{tabular}

Sumber : BPS Kabupaten Cirebon, 2011.

*) Angka Perbaikan

**) Angka Sementara

\section{GAMBARAN UMUM EKONOMI DAN SOSIAL KABUPATEN CIREBON}

Kabupaten Cirebon secara geografis terletak di bagian timur wilayah Provinsi Jawa Barat dan merupakan batas, sekaligus sebagai pintu gerbang Provinsi Jawa Tengah. Wilayah ini berada pada posisi $108^{\circ} 40^{\prime} \mathrm{BT}-108^{\circ} 48^{\prime} \mathrm{BT}$ dan $6^{\circ} 30^{\prime} \mathrm{LS}-7^{\circ} 00^{`} \mathrm{LS}$ dengan batas- batas wilayah administrasi sebagai berikut:

$\begin{array}{lll}\checkmark & \text { Sebelah Utara } & \text { : Kabupaten Indramayu } \\ \checkmark & \text { Sebelah Barat Laut } & \text { : Kabupaten Majalengka } \\ \checkmark & \text { Sebelah Selatan } & \text { : Kabupaten Kuningan } \\ \checkmark & \text { SebelahTimur } & \text { : Kota Cirebon \& Kabupaten Brebes-Jateng }\end{array}$

Luas wilayah keseluruhan $990.36 \mathrm{~km}^{2}$ dengan ketinggian sebesar 0-130 m dari permukaan laut. Letak daratannya memanjang dari Barat Laut ke Tenggara. Kabupaten Cirebon merupakan bagian dari wilayah Provinsi Jawa Barat yang terletak di bagian timur dan merupakan batas,sekaligus sebagai pintu gerbang Provinsi Jawa Tengah. Dalam sektor pertanian Kabupaten Cirebon merupakan salah satu daerah produsen beras yang terletak di jalur pantura. 


\subsection{Gambaran Umum Kependudukan Kabupaten Cirebon}

Jumlah penduduk di Kabupaten Cirebon dari tahun 2005 hingga tahun 2010 belum merata. Data terbaru yang didapat yaitu jumlah penduduk Kabupaten Cirebon pada tahun 2010 mencapai 2.067.196 jiwa. Laju pertumbuhan penduduk Kabupaten Cirebon dari tahun 2000 sampai dengan 2010 yaitu sebesar 0,70 persen. Dengan luas wilayah 990,36 Km2, maka ratarata setiap Km2 ditempati penduduk sebanyak 2.087 orang pada tahun 2010. Secara umum jumlah penduduk laki-laki lebih banyak dibandingkan jumlah penduduk perempuan. Hal ini ditunjukkan oleh sex ratio yang nilainya lebih besar dari 100. Pada tahun 2010, sex ratio sebesar 105,13 yang berarti untuk setiap 100 penduduk perempuan terdapat 105 penduduk laki-laki. Data tersebut dapat dilihat pada Tabel 4.1.

Tabel 2.1. Indikator Kependudukan Kabupaten Cirebon

\begin{tabular}{|l|c|}
\hline \multicolumn{1}{|c|}{ Uraian } & Tahun 2010 \\
\hline Jumlah Penduduk (jiwa) & 2.067 .196 \\
\hline Laju Pertumbuhan Penduduk 2000-2010 (\%) & 0,70 \\
\hline Kepadatan Penduduk (jiwa/Km ${ }^{2}$ ) & 2.087 \\
\hline Rasio Jenis Kelamin & 105,13 \\
\hline Jumlah Rumahtangga & 547.786 \\
\hline Rata-rata ART per Rumahtangga & 3,77 \\
\hline
\end{tabular}

Sumber : BPS Kabupaten Cirebon, 2010.

Penyebaran penduduk Kabupaten Cirebon perkecamatan hingga pada tahun 2010 masih menunjukkan kondisi kurang merata seperti tahun-tahun sebelumnya. Penduduk terbesar terdapat di Kecamatan Sumber yaitu sebanyak 80.950 jiwa dengan sebaran penduduknya sebesar 3,29 persen dan yang terkecil adalah Kecamatan Pasaleman dengan jumlah penduduk hanya 24.968 jiwa dengan sebaran penduduk sebesar 1,21 persen.

\subsection{Gambaran Umum Ketenagakerjaan Kabupaten Cirebon}

Salahsatu modal penting dalam proses meningkatkan pertumbuhan ekonomi dan menyukseskan program pembangunan adalah tenaga kerja. Jumlah tenaga kerja di suatu daerah harus diimbangi dengan ketersediaan lapangan pekerjaan. Selain itu banyaknya jumlah penduduk pun harus diimbangi dengan pertumbuhan angkatan kerja agar tidak memunculkan pengangguran.

Tenagakerja di Kabupaten Cirebon pada tahun 2005 hingga tahun 2010 dari tahun ke tahunnya cenderung menurun. Sehingga pada tahun 2009 pemerintah Kabupaten Cirebon melaksanakan padat karya agar dapat menyerap lebih banyak tenaga kerja. Di Kabupaten Cirebon lapangan pekerjaan yang banyak digeluti masyarakatnya adalah sektor primer (pertanian dalam arti luas termasuk perikanan dan peternakan), diikuti sektor sekunder (industri pengolahan, listrik,gas dan air bersih dan konstruksi) sisanya kedalam sektor tersier ( jasa transportasi, keuangan, dan lain sebagainya).

\subsection{Gambaran Umum Pendidikan Kabupaten Cirebon}

Pendidikan sangat erat kaitannya dengan ketersediaan fasilitas pendidikan. Fasilitas-fasilitas pendidikan dari tahun 2005 hingga tahun 2010 selalu ditingkatkan agar tercapainya standar pendidikan yang lebih baik pula. Data terbaru didapat yaitu pada jenjang pendidikan SD di Kabupaten Cirebon tahun ajaran 2010/2011 seorang guru SD rata-rata mengajar 30 murid SD. Jurnal al-Muzara' ah, Vol. I, No. 1, 2013 
Semakin tinggi jenjang pendidikan maka beban seorang guru semakin sedikit dimana untuk jenjang pendidikan SLTP rata-rata seorang guru mengajar 19 murid dan di jenjang SLTA beban seorang guru hanya mengajar 14 murid saja.

Untuk jenjang pendidikan SLTA baik negeri maupun swasta di Kabupaten Cirebon pada tahun 2010 tetapi pada jenjang pendidikan Sekolah Menengah Umum terjadi penurunan dari sebanyak 19.008 murid pada tahun 2009 menjadi 16.788 murid pada tahun 2010. Pada tahun 2009 persentase penduduk laki-laki berumur 10 tahun ke atas yang masih bersekolah lebih tinggi dari penduduk perempuan yaitu sebesar 18,38 persen, sedangkan penduduk perempuan berumur 10 tahun ke atas yang masih bersekolah sebesar 16,99 persen. (Suseda 2009).

\section{Gambar 1. Persentase Penduduk 10 Tahun ke Atas Menurut Ijazah Tertinggi yang Dimiliki}

\section{Persentase Penduduk 10 Tahun ke Atas Menurut ljazah tertinggi Yang Dimiliki}

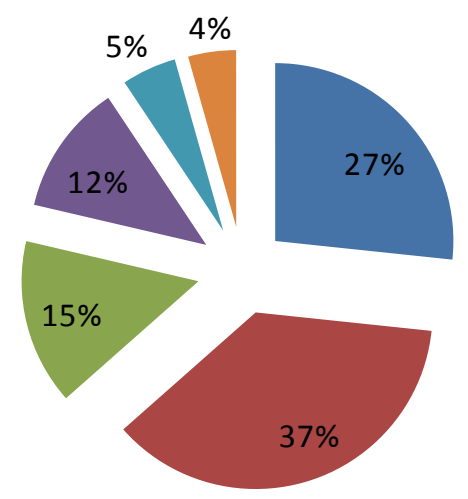

$$
\begin{aligned}
& \text { Tidak Punya } \\
& \text { SD/MI } \\
& \text { SLTP/MTs Sederajat } \\
& \text { SLTA Sederajat } \\
& \text { SM Kejuruan } \\
& \text { Perguruan Tinggi }
\end{aligned}
$$

Sumber : Survei Sosial Ekonomi Daerah, 2009.

\subsection{Gambaran Umum Fasilitas Kesehatan Kabupaten Cirebon}

Kesehatan termasuk salah satu faktor penting dalam pembangunan suatu daerah. Pemerintah Kabupaten Cirebon selalu mengupayakan dan meningkatkan fasilitas-fasilitas kesehatan. Dapat dilihat peningkatan fasilitas-fasilitas kesehatan Kabupaten Cirebon dari tahun 2005 hingga tahun 2010 cukup baik walaupun belum terlalu signifikan. Data terbaru yang didapat yaitu fasilitas kesehatan yang ada di Kabupaten Cirebon pada tahun 2010 yaitu terdapat sebanyak 7 Rumah Sakit Umum, 283 Puskesmas yang terdiri dari 56 Puskesmas Umum, 56 Puskesmas Pembantu, dan 171 Puskesmas Keliling. 
Tabel 2.2. Statistik Fasilitas Kesehatan Kabupaten Cirebon Tahun 2005-2010

\begin{tabular}{|l|c|c|c|c|c|c|}
\hline \multirow{2}{*}{ Uraian } & \multicolumn{7}{|c|}{ Perkembangan Fasilitas Kesehatan } \\
\cline { 2 - 7 } & $\mathbf{2 0 0 5}$ & $\mathbf{2 0 0 6}$ & $\mathbf{2 0 0 7}$ & $\mathbf{2 0 0 8}$ & $\mathbf{2 0 0 9}$ & $\mathbf{2 0 1 0}$ \\
\hline RSU & 6 & 6 & 6 & 6 & 6 & 7 \\
\hline Puskesmas & & & & & & \\
\hline \multicolumn{1}{|c|}{ Umum } & 53 & 58 & 53 & 53 & 53 & 56 \\
\hline Pembantu & 63 & 64 & 66 & 67 & 65 & 56 \\
\hline Keliling & 44 & 58 & 63 & 58 & 208 & 171 \\
\hline Balai Pengobatan & 137 & 171 & 110 & 55 & 77 & 53 \\
\hline Klinik Bersalin & 7 & 5 & 5 & 33 & 26 & 6 \\
\hline BKIA & - & 53 & - & 35 & 51 & - \\
\hline BP gigi & 31 & 31 & - & 44 & 15 & - \\
\hline Apotik & 71 & 74 & 79 & 76 & 68 & 103 \\
\hline Sund
\end{tabular}

Sumber : Dinas Kesehatan Kabupaten Cirebon, 2011.

\section{EKONOMI POLITIK SEKTOR-SEKTOR UNGGULAN KABUPATEN CIREBON}

Dalam hal sektor unggulan, pendekatan yang digunakan biasanya menggunakan pendekatan Location Quotient (LQ). Pada umumnya Produk Domestik Bruto Regional (PDRB) adalah indikator pendekatan LQ ini, sehingga dapat lebih menspesifikasikan antara sektor unggulan dan sektor non-unggulan yang peranannya berkaitan dengan pendapatan dan pertumbuhan wilayah Kabupaten Cirebon.

Penelitian ini menggunakan periode dari tahun 2005 hingga tahun 2010 dan menggunakan PDRB Harga Konstan baik PDRB Kabupaten Cirebon maupun PDRB Provinsi Jawa Barat. Penelitian ini menggunakan periode tersebut dikarenakan laju pertumbuhan ekonomi Kabupaten Cirebon pada tahun 2005 hingga 2010 lebih besar daripada tahun-tahun sebelumnya dan mengalami peningkatan setiap tahunnya, walau ada perlambatan di tahun 2008 dan 2010. Laju perekonomian Kabupaten Cirebon mencapai pertumbuhan tertinggi dalam tahun 2007 yaitu sebesar 7,32 persen walaupun mengalami penurunan kembali pada tahun berikutnya.

Nilai LQ merupakan indikator untuk menyatakan sektor unggulan dan non-unggulan. Ketika suatu sektor memiliki nilai LQ lebih besar dari satu maka sektor tersebut termasuk kedalam sektor unggulan, yaitu artinya peranan suatu sektor dalam perekonomian Kabupaten Cirebon lebih besar daripada peranan sektor tersebut dalam perekonomian Provinsi Jawa Barat. Hasil perhitungan analisis LQ menurut pendekatan pendapatan untuk seluruh sektor yang ada di Kabupaten Cirebon, yaitu sebagai berikut : 
Tabel 3.1. Nilai LQ Sektor Perekonomian Kabupaten Cirebon Tahun 2005-2010

\begin{tabular}{|l|l|l|l|l|l|l|}
\hline \multirow{2}{*}{ Lapangan Usaha } & \multicolumn{7}{c|}{ Nilai LQ } \\
\cline { 2 - 7 } & $\mathbf{2 0 0 5}$ & $\mathbf{2 0 0 6}$ & $\mathbf{2 0 0 7}$ & $\mathbf{2 0 0 8}$ & $\mathbf{2 0 0 9}$ & $\mathbf{2 0 1 0}$ \\
\hline 1. Pertanian & 2.18 & 2.21 & 2.30 & 2.39 & 2.24 & 2.29 \\
\hline 2. Pertambangan/ Penggalian & 0.14 & 0.15 & 0.15 & 0.17 & 0.16 & 0.17 \\
\hline 3. Industri Pengolahan & 0.36 & 0.36 & 0.34 & 0.33 & 0.33 & 0.32 \\
\hline 4. Listrik, Gas dan Air Bersih & 0.89 & 0.99 & 1.01 & 1.02 & 0.92 & 0.95 \\
\hline 5. Bangunan/Kontruksi & 2.07 & 2.14 & 2.18 & 2.15 & 2.13 & 2.03 \\
\hline $\begin{array}{l}\text { 6. Perdagangan, Hotel dan } \\
\text { Restoran }\end{array}$ & 1.13 & 1.16 & 1.13 & 1.16 & 1.11 & 1.06 \\
\hline $\begin{array}{l}\text { 7. Pengangkutan dan Komunikasi } \\
\text { 8. Keuangan, Persewaan dan Jasa } \\
\text { Perusahaan }\end{array}$ & 1.37 & 1.38 & 1.35 & 1.38 & 1.33 & 1.24 \\
\hline 9. Jasa-Jasa & 1.65 & 1.47 & 1.37 & 1.38 & 1.36 & 1.34 \\
\hline Sum & 1.64 & 1.77 & 1.86 & 1.90 & 1.92 \\
\hline
\end{tabular}

Sumber : BPS Kabupaten Cirebon Tahun 2005-2010 (diolah).

Berdasarkan tabel diatas, sektor yang termasuk pada sektor unggulan di Kabupaten Cirebon adalah :

\section{a. Sektor Pertanian}

Pada periode 2005-2010, nilai koefisien LQ > 1, dimana artinya kontribusi sektor pertanian dalam perekonomian Kabupaten Cirebon lebih besar daripada kontribusi sektor tersebut dalam perekonomian Provinsi Jawa Barat. Pesatnya pertumbuhan sektor ini juga karena ketersediaan kekayaan alam yang melimpah di Kabupaten Cirebon. Kabupaten Cirebon merupakan salah satu daerah produsen beras yang terletak di jalur pantura.

\section{b. Bangunan/Konstruksi}

Pada periode 2005-2010, nilai koefisien LQ > 1, dimana artinya kontribusi sektor bangunan/konstruksi dalam perekonomian Kabupaten Cirebon lebih besar daripada kontribusi sektor tersebut dalam perekonomian Provinsi Jawa Barat. Sektor ini merupakan sektor unggulan peringkat kedua setelah sektor pertanian. Sektor bangunan/konstruksi ini mencakup kegiatan pembangunan fisik (konstruksi), baik yang digunakan sebagai tempat tinggal atau sarana lainnya yang dilakukan oleh perusahaan konstruksi maupun yang dilakukan oleh perorangan. Misalnya saja baru-baru ini Kabupaten Cirebon membangun Mall yaitu Cirebon Square dan Plumbon Square yang rencana pembangunannya akan berjalan pada saat ini hingga beberapa waktu kedepan.

\section{c. Jasa-Jasa}

Pada periode 2005-2010, nilai koefisien LQ > 1, dimana artinya kontribusi sektor jasa-jasa dalam perekonomian Kabupaten Cirebon lebih besar daripada kontribusi sektor tersebut dalam perekonomian Provinsi Jawa Barat. Hal ini dikarenakan terjadinya pertumbuhan yang cepat akibat banyaknya penambahan jasa sosial kemasyarakatan, jasa hiburan, rekreasi, jasa perseorangan dan rumah tangga. Jasa sosial kemasyarakatan seperti dibukanya rumah sakit swasta, klinik swasta, sekolah-sekolah swasta, kursus-kursus, riset atau penelitian, palang merah, panti asuhan, panti wreda, Yayasan Pemeliharaan Anak Cacat (YPAC), rumah ibadat dan sejenisnya, baik yang dikelola oleh pemerintah maupun swasta yang ada di Kabupaten Cirebon. 


\section{d. Keuangan, Persewaan, dan Jasa Perusahaan}

Pada periode 2005-2010, nilai koefisien LQ > 1, dimana artinya kontribusi sektor keuangan, persewaan, dan jasa perusahaan dalam perekonomian Kabupaten Cirebon lebih besar daripada kontribusi sektor tersebut dalam perekonomian Provinsi Jawa Barat. Dalam sektor ini, terdapat bank komersial, asuransi, dana pensiun, pegadaian, koperasi simpan pinjam, dan lembaga pembiayaan mengalami peningkatan setiap tahunnya.Sedangkan sektor persewaan di Kabupaten Cirebon mencakup kegiatan usaha persewaan bangunan dan tanah, baik yang menyangkut bangunan tempat tinggal maupun sarana fasilitas umum. Sedangkan sektor jasa perusahaan di Kabupaten Cirebon mencakup kegiatan pemberian jasa hukum, jasa pengolahan dan penyajian data, jasa bangunan atau arsitek dan teknik, jasa periklanan dan riset pemasaran, serta jasa persewaan mesin, peralatan dan lain sebagainya.

\section{e. Pengangkutan dan Komunikasi}

Pada periode 2005-2010, nilai koefisien LQ > 1, dimana artinya kontribusi sektor pengangkutan dan komunikasi dalam perekonomian Kabupaten Cirebon lebih besar daripada kontribusi sektor tersebut dalam perekonomian Provinsi Jawa Barat. Sektor ini sangat dipengaruhi oleh sektor-sektor lainnya diantaranya khususnya sektor pertanian dan sektor industri pengolahan seperti industri rotan, industri tekstil, industri sandal, sepatu dan lain sebagainya. Pengangkutan dan komunikasi ini memiliki peran penting dalam perekonomian Kabupaten Cirebon. Sektor komunikasipun kian meningkat sejalan peningkatan sektor transportasi (pengangkutan).

\section{f. Perdagangan, Hotel dan Restoran}

Pada periode 2005-2010, nilai koefisien LQ > 1, dimana artinya kontribusi sektor perdagangan, hotel dan restoran dalam perekonomian Kabupaten Cirebon lebih besar daripada kontribusi sektor tersebut dalam perekonomian Provinsi Jawa Barat. Pesatnya perkembangan sektor ini didukung adanya objek wisata dan seni budaya yang ada di Kabupaten Cirebon ini. Walaupun dari data yang ada tamu yang menginap di hotel masih didominasi tamu domestik daripada tamu mancanegara. Kabupaten Cirebon merupakan perbatasan antara Jawa Barat dan Jawa Tengah sehingga pusat perekonomian dan perdagangan terpusat pada daerah tersebut. Itulah yang menjadikan sektor perdagangan semakin meningkat dan merupakan sektor unggulan. Sektor restoran pun tidak kalah, pertumbuhan yang pesat pada sektor ini didukung oleh adanya keanekaragaman makanan khas Kabupaten Cirebon yang ada di Kabupaten Cirebon. Makanan khasnya seperti : nasi jamblang, empal gentong, bubur sop, nasi lengko Cirebon, tahu gejrot, doclang, makanan seafood sejenis cumi yang disebut oleh masyarakat sana blakutak, udang, rajungan dan lain sebagainya.

\section{g. Listrik, Gas dan Air Bersih}

Jika dilihat dari hasil analisis LQ di atas, sektor ini termasuk sektor non-unggulan. Tetapi pada tahun 2007 dan 2008, sektor ini sempat masuk ke dalam golongan sektor unggulan di Kabupaten Cirebon. Dalam sektor listrik, gas dan air bersih pada tahun 2007 dan 2008 nilai koefisien LQ > 1, dimana artinya kontribusi sektor listrik, gas dan air bersih dalam perekonomian Kabupaten Cirebon lebih besar daripada kontribusi sektor tersebut dalam perekonomian Provinsi Jawa Barat.

Pada tahun 2009, sektor ini kembali menurun dan tidak tergolong sektor unggulan kembali. Dilihat dari analisis LQ tersebut, sektor ini pada tahun 2007 dan 2008 memiliki nilai koefisien LQ > 1 walaupun mengalami penurunan di tahun berikutnya. Berdasarkan penjelasan sebelumnya terlihat bahwa, sektor ini memiliki potensi untuk menjadi sektor unggulan karena Jurnal al-Muzara'ah, Vol. I, No. 1, 2013 
sektor ini sebagai salah satu sumber utama energi penggerak mesin-mesin produksi pada industri pengolahan. Untuk itu perlu adanya dorongan yang kuat dari Pemerintah Kabupaten Cirebon.

Berdasarkan analisis LQ pada Tabel 5.1, adapun sektor-sektor perekonomian Kabupaten Cirebon yang termasuk ke dalam sektor non-unggulan yaitu: industri pengolahan, pertambangan/penggalian serta sektor listrik, gas dan air bersih.

Seperti yang kita ketahui, bahwasanya Cirebon terkenal dengan sentra industri pengolahan rotan. Kondisi ekspor rotan yang kian meningkat dari tahun ke tahunnya. Hal ini menunjukkan tanda-tanda bahwa sektor industri pengolahan rotan ini merupakan sektor unggulan di Kabupaten Cirebon. Tetapi dari hasil analisis LQ di atas, industri pengolahan tidak termasuk kedalam sektor unggulan. Hal ini disebabkan karena penelitian ini dilakukan dalam periode 2005 hingga 2010, pada pertengahan tahun 2005 pemerintah mengeluarkan kebijakan rotan mentah yang diatur dalam SK No. 12/M-DAG/PER/6/2005 tentang Pembebasan Ekspor Rotan Mentah.

Adanya Kebijakan ekspor rotan mentah ini, mengakibatkan krisis pada perkembangan industri rotan tersebut dengan ditandai menurunnya persediaan bahan baku rotan domestik dan meningkatnya harga bahan baku rotan. Sejak saat itu industri rotan mengalami krisis bahan baku yang mengakibatkan penurunan pada volume dan nilai ekspor. Sehingga industri pengolahan rotan pun perkembangannya menurun setelah diberlakukannya kebijakan tersebut pada tahun 2005. Maka dari itu industri rotan termasuk pada sektor non-unggulan dalam periode 2005-2010 karena adanya kebijakan pembebasan ekspor rotan mentah. Selain itu industri pengolahan bukan hanya industri pengolahan rotan saja, industri pengolahan tekstil, sandal, sepatu dan lain sebagainya.

Dalam hal sektor pertambangan/penggalian khususnya untuk wilayah Kabupaten Cirebon kegiatan yang ada hanyalah subsektor penggalian. Tidak adanya sektor pertambangan disebabkan oleh kondisi alam Kabupaten Cirebon yang tidak berpotensi untuk dilakukannya kegiatan pertambangan seperti halnya di daerah Kalimantan. Akibatnya sektor pertambangan/penggalian ini tidak termasuk kedalam sektor unggulan. Sedangkan untuk sektor listrik, gas, dan air bersih pun termasuk kedalam sektor non-unggulan tetapi pada tahun 2007 dan 2008 sektor ini berpotensi kedalam sektor unggulan di Kabupaten Cirebon.

\section{PERTUMBUHAN SEKTOR EKONOMI UNGGULAN DI KABUPATEN CIREBON}

Nilai riil PDRB Kabupaten Cirebon pada tahun 2005 atas dasar harga konstan tahun 2000 adalah sebesar Rp 6,34 triliun dan meningkat pada tahun 2010 menjadi Rp 8,13 triliun, sehingga pada periode 2005-2010 terjadi peningkatan dengan pertumbuhan sekitar Rp 1,78 triliun. Persentase pertumbuhan semua sektor perekonomian di Kabupaten Cirebon pada periode 2005 sampai dengan 2010 menunjukkan peningkatan kontribusi sebesar 271,91 persen ( Tabel 5.2).

Pada Tabel 5.2 jelas terlihat bahwa presentase pertumbuhan perekonomian tertinggi adalah sektor jasa-jasa yaitu sebesar 46,58 persen. Pada tahun 2005 kontribusi sektor jasa-jasa yang diberikan terhadap PDRB Kabupaten Cirebon adalah sebesar Rp 726,34 miliar dan meningkat pada tahun 2010 sebesar Rp 1,06 triliun, sehingga pada periode 2005 hingga 2010 sektor jasajasa meningkat sebesar Rp 338,34 miliar. Maka dari itu sektor jasa-jasa di Kabupaten Cirebon tumbuh pesat. Hal ini dikarenakan banyaknya penambahan baik jasa sosial kemasyarakatan, jasa hiburan, rekreasi maupun jasa perseorangan dan rumahtangga oleh pemerintah Kabupaten Cirebon. Selain itu juga di dukung oleh faktor seni budaya Cirebon dalam hal jasa 
hiburan dan kesenian seperti grup tarling, wayang golek, tari topeng dan sebagainya. Adapun tabel pertumbuhan PDRB Kabupaten Cirebon, yaitu sebagai berikut :

Tabel 4.1. Perubahan PDRB Kabupaten Cirebon Menurut Lapangan Usahanya Berdasarkan Harga Konstan 2000, Tahun 2005 dan 2010 (juta rupiah)

\begin{tabular}{|l|r|r|r|r|}
\hline \multicolumn{1}{|c|}{ Lapangan Usaha } & \multicolumn{1}{c|}{$\mathbf{2 0 0 5}$} & \multicolumn{1}{c|}{$\mathbf{2 0 1 0}$} & \multicolumn{1}{c|}{$\Delta$ PDRB } & \multicolumn{1}{c|}{ Persen } \\
\hline 1.Pertanian & 1.989 .626 & $2.442 .050,77$ & 452.425 & 22,74 \\
\hline 2.Pertambangan/penggalian & 26.237 & $32.019,35$ & 5.782 & 22,04 \\
\hline 3. Industri Pengolahan & $\mathbf{1 . 0 0 3 . 8 5 5}$ & $\mathbf{1 . 0 9 7 . 5 4 2 , 2 3}$ & $\mathbf{9 3 . 6 8 7}$ & $\mathbf{9 , 3 3}$ \\
\hline 4. Listrik, Gas dan Air Bersih & 131.926 & $175.847,56$ & 43.922 & 33,29 \\
\hline 5. Bangunan/Konstruksi & 421.073 & $605.021,72$ & 183.949 & 43,69 \\
\hline $\begin{array}{l}\text { 6. Perdagangan, Hotel dan restoran } \\
\text { 7. Pengangkutan dan Komunikasi }\end{array}$ & 1.400 .054 & $1.873 .433,74$ & 473.380 & 33,81 \\
\hline $\begin{array}{l}\text { 8. Keuangan, Persewaan dan jasa } \\
\text { Perusahaan }\end{array}$ & 274.813 & $356.997,47$ & 82.184 & 29,91 \\
\hline 9. Jasa-jasa & 726.344 & $1.064 .684,34$ & 338.340 & 46,58 \\
\hline Total PDRB & $\mathbf{6 . 3 4 3 . 7 7 9}$ & $\mathbf{8 . 1 3 0 . 3 2 5 , 0 7}$ & $\mathbf{1 . 7 8 6 . 5 4 6}$ & $\mathbf{2 8 . 1 6}$ \\
\hline
\end{tabular}

Sumber : BPS Kabupaten Cirebon, 2011 (diolah).

Persentase pertumbuhan perekonomian terendah adalah industri pengolahan yang tumbuh sebesar 9,33 persen. Pada tahun 2005 kontribusi industri pengolahan terhadap PDRB Kabupaten Cirebon adalah sebesar Rp 1,00 triliun dan meningkat pada tahun 2010 menjadi sebesar Rp 1,09 triliun. Selama periode 2005 hingga 2010 sektor ini meningkat sebesar 9,36 miliar.

Pada sektor industri pengolahan ini menjadi sektor perekonomian yang pertumbuhannya terendah karena adanya kebijakan rotan mentah yang diatur dalam SK No.12/MDAG/PER/6/2005 tentang Pembebasan Ekspor Rotan Mentah. Selain itu industri pengolahan bukan hanya industri pengolahan rotan saja, industri pengolahan tekstil, sandal, sepatu dan lain sebagainya.

\section{EKONOMI POLITIK KEBIJAKAN BUPATI CIREBON DALAM PENINGKATAN PEREKONOMIAN KABUPATEN CIREBON}

Kebijakan yang diterapkan di Kabupaten Cirebon selama periode 2005-2010 itu untuk mencapai agenda pembangunan daerah yaitu dengan meningkatkan mutu sumber daya manusia yang beriman, berakhlak, sehat, berilmu, cerdas, berbudaya dan sejahtera. Jika mutu sumberdayanya meningkat maka akan mendukung pertumbuhan ekonomi yang diharapkan. Kebijakan Pemerintah Kabupaten Cirebon ini direalisasikan melalui program-program kegiatan yang diterapkan pada bidang dan sektornya masing-masing sesuai Peraturan Bupati Cirebon Nomor 92 Tahun 2005 dan Nomor 12 Tahun 2009 tentang Rencana Pembangunan Jangka Menengah Daerah (RPJMD) Kabupaten Cirebon Tahun 2005-2010. Hal ini akan dijelaskan pada uraian selanjutnya.

Struktur perekonomian Kabupaten Cirebon periode 2005-2010, secara keseluruhan memperlihatkan bahwa sektor pertanian sangat dominan. Primadona untuk tanaman pangan yaitu padi, sedangkan primadona untuk palawija yaitu kacang hijau, sayurannya yaitu bawang Jurnal al-Muzara'ah, Vol. I, No. 1, 2013 
merah dan untuk produk buahnya yaitu mangga gedong gincu. Berdasarkan uraian di atas maka kebijakan atau program yang dilakukan yaitu:

1. Meningkatkan produksi pertanian sehingga rata-rata hasil produksi pada tiap kecamatan memiliki proporsi yang sama.

2. Mempertahankan luas areal pertanian dengan pengendalian alih fungsi lahan pertanian produktif menjadi kawasan industri.

3. Pemberdayaan sumberdaya pertanian dan peningkatan kesejahteraan petani.

Penyumbang terbesar lainnya yaitu sektor industri dan perdagangan. Walaupun pertanian masih menjadi dominan di Kabupaten Cirebon, secara perlahan mengalami pergeseran dengan meningkatnya industri dan perdagangan. Pemerintah Kabupaten Cirebon selalu mengupayakan usaha-usaha yang dapat meningkatkan baik sektor industri maupun sektor perdagangan, yaitu melalui kegiatan:

1. Peningkatan investasi.

2. Pemberdayaan pelaku ekonomi.

3. Peningkatan infrastruktur pendukung perekonomian.

4. Peningkatan kerjasama perdagangan internasional.

Selain itu pemerintah juga mengadakan program pelestarian budaya dan pembinaan kesenian daerah, yaitu melalui serangkaian kegiatan:

1. Pemeliharaan bangunan, prasarti, situs bersejarah.

2. Penggalian sejarah dan budaya Kabupaten Cirebon.

3. Pembauran bahasa Cirebon dalam aktifitas masyarakat.

4. Pengaktifan dan peningkatan sanggar-sanggar kesenian dan budaya daerah.

5. Pelaksanaan misi dan pentas kesenian.

Adapun program-program lainnya yang dilakukan Pemerintah Kabupaten Cirebon guna mendukung pertumbuhan ekonomi Kabupaten Cirebon yang berkelanjutan, yaitu sebagai berikut:

1. Program peningkatan investasi melalui kegiatan :
a. Promosi potensi investasi.
b. Pengembangan koordinasi penanaman modal daerah.
c. Sosialisasi kebijakan investasi.
d. Perluasan bentuk kerjasama investasi dengan investor dalam dan luar negeri.
e. Pemberian layanan perijinan investasi.

2. Ketahanan pangan melalui kegiatan :
a. Pembangunan sarana dan prasarana pendukung pertanian, pertanian, peternakan, dan perikanan.
b. Pembinaan bidang usaha pertanian, peternakan dan perikanan.
c. Optimalisasi sumber daya lahan dan meningkatkan mutu intensifikasi.
d. Pengembangan produk olahan (agroindustri) pangan.

3. Penanggulangan kemiskinan melalui kegiatan :
a. Pemberian fasilitas subsidi silang baik dari Pemerintah Pusat maupun Provinsi serta memfasilitasi bantuan program pemerintah.
b. Pemberian bantuan pada keluarga miskin.
c. Pemberian bantuan Modal Usaha pada keluarga miskin. 
4. Peningkatan dalam bidang ketenagakerjaan melalui kegiatan:
a. Peningkatan dayasaing tenagakerja.
b. Perlindungan dan pengawasan ketenagakerjaan.
c. Memfasilitasi penciptaan lapangan pekerjaan.
d. Peningkatan upah minimum dan perlindungan serta pengawasan ketenagakerjaan.

5. Pengembangan usaha industri andalan, dan unggulan, jasa, perdagangan dan pariwisata melalui kegiatan:
a. Pemberian advokasi manajemen, fasilitasi permodalan dan stimulan usaha.
b. Pengembangan kelembagaan usaha masyarakat, koperasi dan Badan Usaha Milik Daerah.
c. Penentuan sentra perdagangan.
d. Peningkatan koordinasi kemitraan.
e. Pembangunan sarana transportasi dan peningkatan teknologi.
f. Peningkatan kualitas sarana dan prasarana pariwisata bestandar internasional.

6. Pengembangan potensi PAD melalui kegiatan:
a. Pendataan potensi objek pajak dan retribusi daerah.
b. Ekstensifikasi dan intensifikasi pendapatan daerah.
c. Uji efisiensi pemungutan pajak dan retribusi pada dinas penghasil.

7. Peningkatan komunikasi dan media massa melalui kegiatan:
a. Publikasi perencanaan, pelaksanaan, dan pengawasan pembangunan.
b. Pelaksanaan forum dialog interaktif (temu wicara dan dialog bersama media).
c. Pengembangan kemitraan dengan pers.

8. Peningkatan kerjasama lembaga keuangan melalui kegiatan:
a. Pengusulan dan penyaluran dana bantuan program.
b. Peningkatan koordinasi pemerintah pusat, provinsi dan lembaga keuangan.
c. Mengusahakan pinjaman kredit lunak.
d. Kerjasama bisnis dengan investor.

9. Regulasi tata ruang dan pengendalian tata guna lahan melalui kegiatan:
a. Verifikasi pembangunan infrastuktur dan perumahan.
b. Penyusunan dokumen rencana tata ruang.
c. Penetapan dan penegasan subyek dan obyek redistribusi tanah kelebihan batas maksimum.
d. Pemetaan penguasaan tanah, meneyelesaikan masalah pertanahan dan member ijin lokasi.
e. Monitoring dan evaluasi pemanfaatan tanah.

Program-program di atas adalah kebijakan-kebijakan di Kabupaten Cirebon yang ada pada periode 2005-2010. Dalam hal ini, sebenarnya masih banyak kebijakan Pemerintah Kabupaten Cirebon berupa program-program kegiatan lainnya. Kebijakan yang ada ini perlu lebih ditingkatkan untuk kedepannya agar pertumbuhan ekonomi yang diharapkan dapat tercapai (BAPEDDA, 2011). 


\section{KESIMPULAN}

Berdasarkan pembahasan hasil penelitian, maka dapat disimpulkan bahwa:

1. Dengan menggunakan metode Location Quotient (LQ), sektor-sektor perekonomian yang termasuk kedalam sektor unggulan di Kabupaten Cirebon pada periode 2005-2010 adalah sektor pertanian, sektor bangunan/konstruksi, sektor jasa-jasa, sektor keuangan, persewaan dan jasa perusahaan, sektor pengangkutan dan komunikasi, dan sektor perdagangan hotel dan restoran.

2. Sedangkan sektor-sektor perekonomian di Kabupaten Cirebon yang termasuk sektor nonunggulan yaitu sektor listrik,gas dan air bersih, sektor industri pengolahan, dan sektor pertambangan dan penggalian.

\section{SARAN}

1. Berdasarkan hasil penelitian ini, Pemerintah Kabupaten Cirebon diharapkan dapat lebih memprioritaskan sektor unggulan yang ada di Kabupaten Cirebon guna mengupayakan peningkatan sektor-sektor unggulan terhadap pertumbuhan ekonomi Kabupaten Cirebon.

2. Pemerintah Kabupaten Cirebon dalam hal ini Bupati Cirebon sebagai Ulil Amri perlu mengalokasikan dana pembinaan yang tepat kepada sektor unggulan terutama sektor industri rotan sebagai industri potensial Kabupaten Cirebon, pascakebijakan berlakunya pemerintah mengeluarkan kebijakan rotan mentah yang diatur dalam SK No. 12/MDAG/PER/6/2005 tentang Pembebasan Ekspor Rotan Mentah. 